\title{
Whole English Immersion Teaching of Optical Images, Interference and Diffraction of University Physics*
}

\section{Huaqiu Deng}

Physics Department, South China University of Technology, Guangzhou 510640, China (hqdeng@ scut.edu.cn)

Abstract - The paper applies whole English immersion teaching on optical images, interference and diffraction of university physics, discusses graphic method, comparison method and discussion method of whole English immersion teaching, and shows that the whole English immersion teaching is an effective one in teaching of optical images, interference and diffraction of university physics.

Keywords - Image, Interference, Diffraction, University physics, Whole English immersion teaching

\section{大学物理光学成像、干涉、衍射的浸泡式全英教学}

\author{
邓华秋 \\ 华南理工大学物理系, 广州, 510640, 中国
}

摘 要 本文将浸泡式教学法应用于大学物理课程光学成像、干涉、衍射部分的全英教学, 讨论了全英浸泡式图解法教学、比较法 教学和课堂讨论法教学, 有效提高了大学物理的教学效果。

关键词 成像, 干涉, 衍射, 大学物理, 浸泡式全英教学

1. 引言

大学物理是理工类高等学校的公共基础课, 内容涉及 力学、热学、电磁学、光学和原子物理学等五大部分, 为 各专业学生进一步的专业学习打下基础。目前国际社会日 益紧密联系, 为了适应中国加入 WTO 的新形势, 迎接国际 挑战, 教育部指出“实施双语教学是我国高等教育适应经济 全球化趋势, 培养具有国际合作意识、国际交流与竞争能力 的外向型人才的重要途径。”[1] 各高校逐渐实行双语教学 [2], 并开始试行全英文教学, 以满足社会对高素质综合性 人才的强烈需求。本文试图就大学物理课程光学成像 (Image)、干涉(Interference)、衍射(Diffraction)内容进行浸泡 式全英文教学研究。

\section{2. 浸泡式教学法及其特点}

浸泡式教学法是将学生置于第二语言的环境氛围中, 以第二语言为媒介教授专业课程。学生在用第二语言学习 专业课程的过程中自然获得第二语言能力。加拿大政府于 二十世纪六十年代为促进国内英语和法语及其文化的交流
与融合, 非常支持北部的法语浸泡式课程。浸泡式教学法具 有八大特点[3-5]:

(1) 第二语言是教学的媒介

（2）浸泡课程与母语课程并行不悖

(3) 明确支持母语

(4) 亦具有双语教学功能

(5) 浸泡多限于课堂之内

(6) 学生的第二语言水平相当或相近

(7) 教师具备双语能力

(8) 课堂文化仍为母语文化。

由于浸泡式教学法具备培养外语能力和专业能力的双 重作用, 二十世纪七十、八十年代被推广到北美及更广的地 区。国内很多高校也开始这方面的教学研究 [6-8]。

\section{3. 大学物理光学成像、干涉、衍射全英教学 \\ 大学物理内容涉及力学、热学、电磁学、光学和原子 物理学等五大部分[9-12], 对象不同、体系不同, 专业英语}

\footnotetext{
* This work is partially supported by "Research and Practice on Constructing Whole English Teaching Model Course - University Physics" of Guangdong Education Bureau and by "Research on Whole English Immersion Teaching of University Physics" of South China University of Technology.
} 
词汇繁杂, 而大学物理全英教学要求用英语编写课件, 教 师在课堂上用英语教授课程内容, 师生用英语提问问题、 解答问题及课堂讨论, 学生用英语完成作业, 期末考试用 英语完成, 因此英语是作为语言媒介在大学物理全英教学 中被师生使用。由于学生的母语是中文, 不是英语, 学生 的逻辑思维是用中文进行的, 全英语课堂教学的效果有赖 于教师用英语对大学物理知识的清楚阐述、学生对有关知 识的及时领悟。如何做到大学物理高质量全英语教学? 浸 泡式全英教学是一个有效途径。让学生浸润在英语环境当 中, 暂时忘记了中文, 尽快形成大学物理英语思维, 即便 不熟悉大学物理各部分的英文专业词汇, 学生也可以及时 跟进大学物理全英教学, 用英语提问、回答, 以及课堂讨 论。

光学 (Optics) 是大学物理的重要内容, 主要讲授成像 (Images)、干涉 (Interference)、衍射 (Diffraction) 等三 部分内容, 目的是让学生掌握光学成像、干涉、衍射的物 理本质及其应用。通常先讲授光学成像, 再讲授光的干涉 和衍射。为了提高浸泡式全英教学效果, 这三部分内容的 教授通过图解、比较及课堂讨论方式进行。

\section{1 光学成像、干涉、衍射的浸泡式全英文图解式教学}

成像、干涉、衍射的浸泡式全英文图解式教学就是利 用多媒体教学工具, 突出图文并茂的教学特点, 用英文讲 清楚成像、干涉、衍射的物理概念及其本质, 藉此可以帮 助学生对成像、干涉、衍射产生直观的物理感受, 帮助学 生清楚了解相关的英文专业词汇。

成像是指光线通过反射镜、透镜、光栏等光学元件的 成像过程, 基础是光的直线传播定律、反射定律、折射定 律, 利用光的粒子特性, 如图1(a)所示。图中显示了凸透镜 将物点 $\mathrm{S}$ 成像于像点 $\mathrm{P}$ 的过程, 图中标明了透镜顶点 $\mathrm{V} 、$ 物 $\mathrm{S}$ 和像 $\mathrm{P} 、$ 物方焦点 $\mathrm{F}_{\mathrm{o}}$ 和像方焦点 $\mathrm{F}_{\mathrm{i}}$ 等信息。

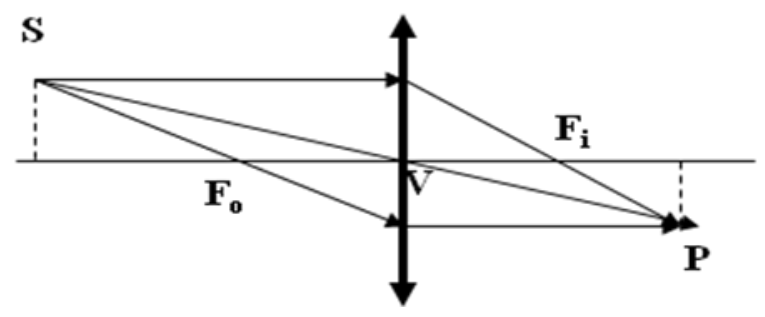

图1. 光学成像过程

光的干涉、衍射是指后续光场的叠加, 基础是惠更斯 -菲涅尔原理, 利用光的波动性质。图2所示杨氏双缝干涉 原理。光源 $\mathrm{S}$ 发出的光经过双缝 $\mathrm{S} 1$ 和 $\mathrm{S} 2$ 在观察面 $\mathrm{Y}$ 形成明暗 相间的干涉图案。

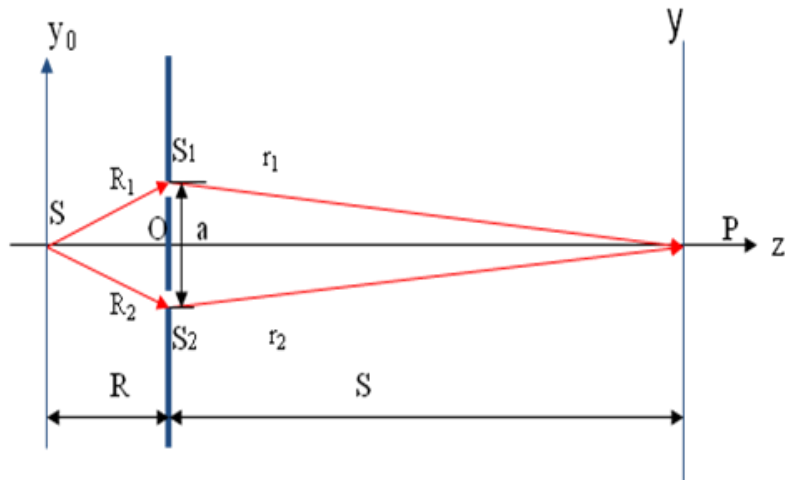

图2. 杨氏双缝干涉原理

3.2 光学成像、干涉、衍射的浸泡式全英文比较教学

光学成像、干涉、衍射的浸泡式全英文比较教学可以 从这三部分内容的基础讨论进行。

几何光学依靠光的三大传播定律: 直线传播定律(Law of Rectilinear propagation)、反射定律(Law of reflection)、折 射定律(Law of refraction)确定成像过程, 基础是费马原理 (Fermat's Principle), 因为从费马的最小时间原理可以推导 出光的三大传播定律。

光的干涉和衍射的基础是惠更斯-菲涅尔原理 (The Huygens - Fresnel Principle)。惠更斯提出子波的概念, 认为 某一时刻波阵面上布满了子波波源, 每个子波波源发出球 面子波, 后一时刻的子波的包络面就形成新的波阵面, 但 忽略了子波很多的细节。菲涅尔基于惠更斯原理, 提出子 波具有母波相同的频率, 后续光场中某一点的振动是所有 不被遮挡的子波的叠加 (Every unobstructed point of a wavefront, at a given instant, serves as a source of spherical secondary wavelets (with the same frequency as that of the primary wave). The amplitude of the optical field at any point beyond is the superposition of all these wavelets (considering their amplitudes and relative phases))[13], 从而克服了惠更斯 原理的局限性。

\section{3 光学成像、干涉、衍射的浸泡式全英文讨论式教学}

光学成像、干涉、衍射的浸泡式全英文讨论式教学就 是通过设置讨论专题, 让学生以小组形式浸泡在英语当中 就专题开展讨论, 以提高光学成像、干涉、衍射的全英文 教学效果, 及时掌握学生对光学成像、干涉、衍射的理解。

由于《大学物理》课程课时少, 课程内容多, 光学成 像、干涉、衍射的全英文课堂讨论时间不宜太长, 15 分钟 为宜, 30 分钟尚可, 太长可能影响课程内容的教授。光学 成像、干涉、衍射的全英文课堂讨论专题视讨论时间而定。 15 分钟的课堂讨论可以设置简单的专题, 如讨论光的直线 
传播定律、反射定律、折射定律，光的干涉叠加原理。 30 分钟的光的成像、干涉、衍射的全英文浸泡式课堂讨论可 以设置稍微复杂的专题, 如就光的粒子特性、波动特性进 行讨论, 等等。学生通过短时间的课堂全英文小组讨论, 锻炼了专业英语的会话能力, 加深了光学成像、干涉、衍 射内容的理解。教师也应该加入到学生课堂讨论当中, 可 以及时了解学生对光学成像、干涉和衍射内容的掌握情况, 并对有关问题做进一步的阐述，加深学生对问题的理解。

\section{4. 结论}

光学成像、干涉和衍射是大学物理的内容, 本文通过 全英浸泡式图解法教学、比较法教学和课堂讨论法教学, 有效提高了大学物理光学成像、干涉、衍射, 得到了华南 理工大学 2012 级土木工程卓越全英班和环境工程全英班 57 名学生的肯定。

\section{参考文献(References)}

[1] Chinese Ministry of Education. Several Opinions on Strengthening Undergraduate Teaching and Improving the Teaching Quality of Colleges and Universities. 2001, Article 4.

[2] DENG Hua-qiu. Research on Methods and Means of Improving Bilingual Teaching. Theory and Practice of Education. 2007, 27 (Monography)

[3] Evans, T.D., Maggie Jo St John. Development in ESP: A Multi-disciplinary Approach. London: Cambridge University Press, 1998

[4] Merrill Swan. French Immersion in Canada: Recent Contribution to SLA and Applied Linguistics. Annual Review of Applied Linguistics, (2000)20:1999-222.

[5] Walker, C.L., Diane J. Tedick. The Complexity of Immersion Education - Teachers Address the Issues. The Modern Language Jounal.2001,(1)

[6] DU Feng-feng. On the Roles of the Instructors Conducting the English Imersion Approach. International Economics and Trade Research. 2005, 21 (Monography)

[7] LU Ming-zhi. Thoughts on the English Immersion Approach to Teaching Business English. International Economics and Trade Research. 2005, 21 (Monography)

[8] CAO Chang-mei, GUO Guo-qing, SHEN Wei-zai. All English immersion teaching in the exploration of regional anatomy. Chinese Journal of Clinical Anatomy. 2008, 26(4):113

[9] ZHANG Li-bin, ZHANG Gong, LI Guang-ping. Measures of Harvard university for improving physics teaching quality. College Physics. 2011, 30(12): 48-64

[10] Xiaolin SHU, Shuo JIN, Ying ZHANG, Hongbo ZHOU, Guanghong LV. Explore How to Carry on the Ability Training in the University Physics Teaching. 2012 Conference on Creative Education

[11] Shi Jian-hua Liang Hong. Explore the effective use of multimedia technology in college physics teaching. 2010 Third International Conference on Education Technology and Training (ETT)

[12] Halliday \& Resnick, Jearl Walker. Fundamentals of Physics (9th Edition), John Wiley \& Sons, Inc.

[13] Eugene Hecht. Optics (Fourth Edition), Higher Education Press 